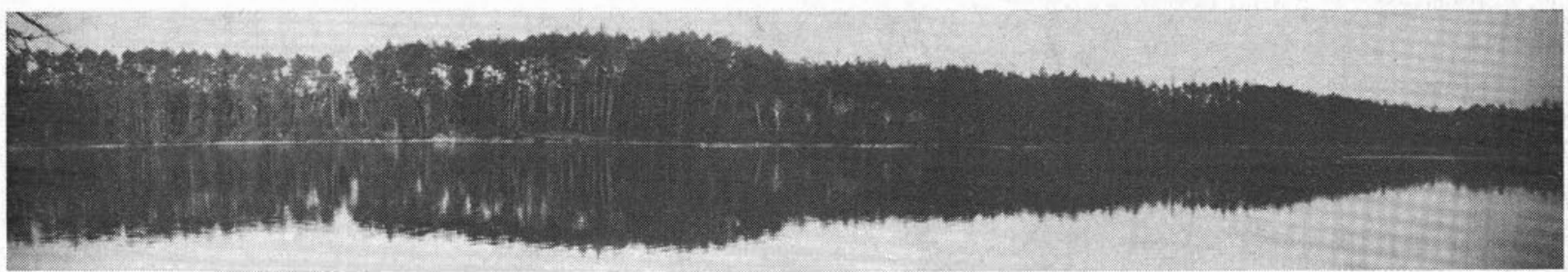

Photographs show the before and after views from the lake of the group (this page) and strip (next page) cuts in the shoreline/skyline reserve. Can you tell which one is which?
This article is based on one by the author which appeared in the Log Book (Jan.-Feb. 1971: 17-19) under the title "Cutting in the Shoreline Reserve of Lake Temegami at Shiningwood Bay'.

\section{Aesthetics and cutting in the shoreline reserve of Lake Temagami}

\author{
D. E. BUCK
}

William Milne \& Sons, Limited Temagami, Ontario

Lake Temagami has often been described as the "pearl" of Northern Ontario Lakes. The title goes undisputed by the tourists that populate the lake in summer and winter, and by the local people. The Lake Temagami area is not only a source of beauty, silence or a place to "re"-create, it also provides the local people with a living in tourism, lumbering or mining. Remarkably, they have managed so far to combine their varying interests in the natural resources of the area in an atmosphere of harmony by:

- respecting each other's interests

- appreciation of opinions on the basis of observation and local experience, rather than excessive preoccupation with histrionics

- recognition of long term rather than short term objectives

- a minimum of outside interference.

As our approach to multiple use, we industry people at Temagami felt that we should conduct practical, limited experiments in the field as an alternative to the seemingly endless and high-flown theoretical debate, which regrettably seems to have characterized the relations between the industrialists and the seekers after the aesthetic. In this approach we were enthusiastically joined by the Ontario Department of Lands and Forests and a number of members of the Temagami Lakes Association who were closest to the problem.
Intervention de coupe dans la bordure de protection du lac Temagami: un exemple de considérations esthétiques. Des coupes expérimentales par groupe et par bande ont été réalisées dans la bordure de protection du lac Temagami en Ontario, après avoir informé la population locale des bénéfices de tels traitements. Le but consistait à renverser la dégradation naturelle causée par l'absence de conditions propices à la régénération du pin.

\section{History of shoreline reserve}

An important segment of the white pine industry depends on the over-mature pine forests of the Temagami area for survival, following the setting aside in 1898 under the Crown Timber Act of the forests as the Temagami Forest Reserve for the express purpose of timber production. At that time even cottages were excluded as a land use potential on islands and mainland alike. Nevertheless, in those days the aesthetic values of the lake were already recognized by all regardless of what interests they represented. Lumber operators consented to assigning the lowest cutting priority to all shoreline stands in the Forest Reserve because abundant supplies of timber were obtainable from inland stands and also because of the relatively early stage of decadence of forests. However, with subsequent generations of forest administrators and with cottage leases being permitted on islands (since 1918), these shoreline stands became known as the Shoreline Reserve. Still later, when private ownership of islands became possible, this Reserve turned into the Skyline Reserve to convey a measure of protection of investments made by cottage owners.

The Skyline Reserve is defined as the area between the shore and the last trees normally visible from any point on the lake.

At the end of the 1950's it became quite clear

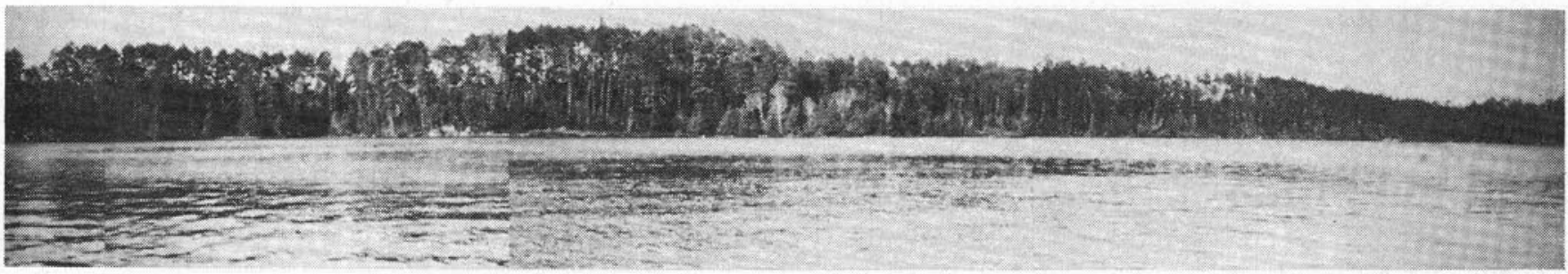




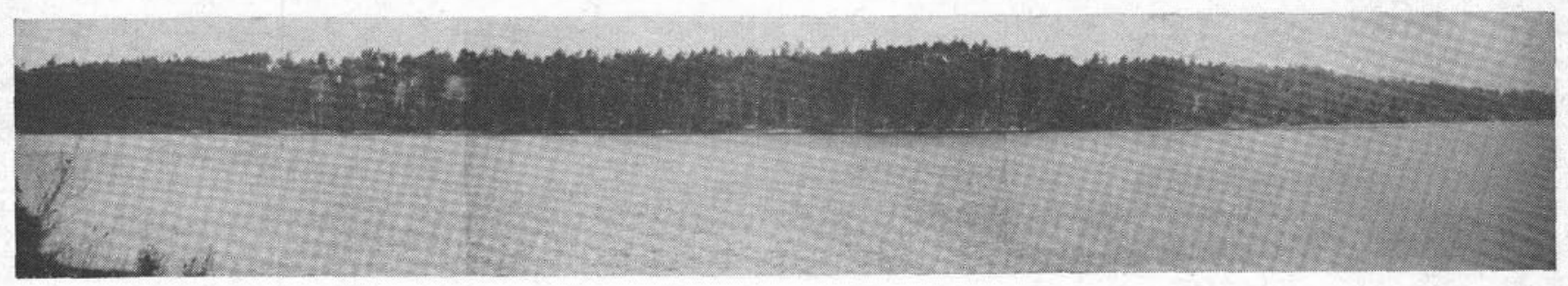

that nature itself was not willing to guarantee the protection so generously bestowed upon cottage owners by man, as tree mortality accelerated and high winds were increasing their tolls.

\section{The forest}

Estimates of the timber in the shoreline range between 150 and 300 million fbm representing a gross sales value of between 25 and 50 million dollars, not counting the economic multiplier effect. In addition it also was recognized that the 250-year-old white and red pine stands along the shoreline could not much longer maintain their place through natural succession.

The openings in the forest caused by natural pine mortality were quickly filled out by stunted balsam fir, cedar and birch which until then were part of the understory. Normally, that is before civilization came to the region, forest fires would wipe out the fir-cedar-birch, leaving only a few tall pine "veterans". The latter in turn would reseed the burn and a young stand of pines would emerge depending on the quality of the seed year and on the season the fire passed. Today, forest fires are immediately de?tected and brought under control, hence natural pine regeneration is the exception rather than the rule.

In summary then, the decline of most pine stands on the shoreline is caused by:

$1 /$ old age

2/ the effect of ecological factors

$3 /$ the inability of old pine stands to regenerate themselves by natural means.

\section{Effect of artificial openings}

Company and government foresters studied these problems in the late 1950's and consequently strip cutting on Lake Temagami's Joan Peninsula was started in 1961. This experiment showed that satisfactory natural regeneration could be obtained by increasing the light intensity, by subsequent scarification of the seedbed, and through the availability of seed.

\section{Public information}

In 1968 the Ontario Department of Lands and Forests and William Milne \& Sons Ltd. undertook a program directed at informing the local people of the area as well as all members of the Temagami Lakes Association about the conditions in the Shoreline Reserve.

The objectives of experimental shoreline cuttings were outlined to the public as follows:

1/ To perpetuate the beauty of Lake Temagami by providing favorable conditions for regeneration of white and red pine.

2/ To use instead of waste a valuable renewable resource.

3/ To prevent the shoreline from becoming a socalled "forest slum".

In addition the advantages were mentioned of obtaining information about forest management entirely within the framework of aesthetics.

Although public reaction at first was about equally divided, it decidedly favored the implementation of our objectives after groups of interested people were shown, on the spot, what was done, how well it could be done and the indisputable long term advantages of intensive forest management of the Shoreline Reserve. Such a reaction became even stronger shortly after a tornado devastated the shoreline along a five-mile-long path. The enormous windfall demonstrated that root and ground rots had greatly impaired the function of the roots to anchor the overmature trees to the ground.

\section{Cutting the skyline reserve}

In 1967, William Milne \& Sons Ltd. submitted a plan for selective group cuts within the Skyline Reserve. It was approved by the Ontario Department of Lands and Forests and put into effect in 1968-69. In 1969 a second plan was submitted which proposed a contour strip cut in the adjacent area; the cut was carried out in 1970.

Site characteristics were similar in both cuts, except for the direction of exposure. Average basal area was $145 \mathrm{sq} \mathrm{ft} /$ acre. Because of the greater

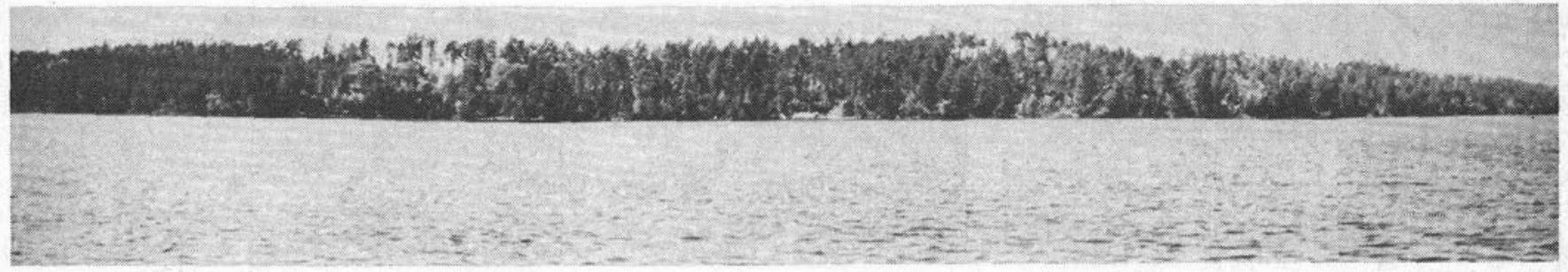

October 1971 The Forestry Chronicle 
challenges involved the Company decided to select shoreline sections in which the total width of the Reserve was only 6 chains. In both cases the difference in elevation between the lake level and highest point in the reserve area was 85 feet.

Group cut. The 1968-69 cut consisted of group cuts. First, a hundred-foot wide "inviolable" shoreline reserve was laid out from the water's edge.

The group cut aimed at creating openings of approximately $1 / 3$ acre by removing groups of 10 to 14 trees in the (remaining) reserve area. The selection of trees around group centers was tied to factors such as advance growth present, tree condition and topography, not to any geometrical plot pattern. Group centers were laid out 250 to $300 \mathrm{ft}$ apart.

Cutting and skidding by a specially selected and trained two-man crew took place between December 1968 and February 1969. Directional felling techniques were used to spare advance growth present and to minimize felling damage to the surrounding standing trees. Timber was skidded by wheeled skidder in log lengths (to minimize skidding damage) to primary landings, mostly behind the Reserve. From there it was truck hauled to the mill. All tops were lopped at the time of cutting. Between April 25 and May 10, 1970, the openings were cleared of unmerchantable residual trees. This material and the logging slash were piled and burned on 8 group-areas. A similar, although not quite as neat looking effect, was obtained on the 7 remaining group-areas by scarification with a bulldozer blade. This work was followed up by tree planting of 3-0 red pine stock.

A total of $72,000 \mathrm{fbm}$ of red pine, white pine and spruce was harvested on the 15 group-areas. This volume constituted approximately $22 \%$ of the merchantable volume available in the reserve area concerned.

In conclusion, the group cutting proved very effective from an aesthetic point of view, with disturbance virtually imperceptible from the lake. Furthermore, the road through the reserve area has now obtained an attractive "landscaped" look in contrast to the former "tunnel" effect. However, since the logging procedure as well as the follow-up treatment were complicated on the small, separated group-areas, the subsequent cut of 1969-70 employed the strip cut method.

Strip cut. A hundred-foot wide "inviolable" reserve was again laid out from the water's edge, followed by marking of the $100-\mathrm{ft}$ wide contour strip. This strip ran parallel to the $975 \mathrm{ft}$ elevation contour except where the contour infringed on the "inviolable" reserve. In those cases it was raised to the $1000 \mathrm{ft}$ contour level.
The strip was cut and "full" trees taken to behind the Skyline Reserve with wheeled skidders, where they were limbed, bucked into logs and piled. Tops and other logging debris were burned as they accumulated at the landing. However, due to very low temperatures $\left(-20^{\circ} \mathrm{F}\right)$ during the operation (January 1970), most of the branches and frequently the tops broke off upon felling. It was therefore found more convenient to burn the debris and unmerchantable trees right inside the strip immediately following skidding of the merchantable stems and before fresh snow covered them up. The cutting, skidding and burning phase of the operation was carried out by a 3-man crew, the "burner" working on piece work. The skidder was allowed 2 hours per day for piling and bunching of debris.

This cut utilized approximately $33 \%$ of the available timber of the reserve area concerned. The volume harvested was $206,000 \mathrm{fbm}$ of white and red pine and spruce. In May 1970 the cut-over strip was scarified and planted with 3-0 red pine stock under the Company's Regeneration Agreement.

In retrospect, the strip cut proved only slightly more severe than the group cuts when viewed from the Lake (despite utilization of up to $15 \%$ more timber). When viewed from inside the reserve the aesthetics of the strip cut were not nearly as pleasant as those of the group cut, but there was a considerable saving in lay-out and supervisory procedures. Also cutting, skidding and follow-up treatment were greatly simplified.

\section{Epilogue}

In January of 1971 the Department of Lands and Forests issued questionnaires to all property owners on Lake Temagami to discover any sub-currents of public opinion for consideration in their proposed Master Land-Use Plan. The general response to questions requiring spontaneous replies was excellent. When asked to indicate what the property owners felt to be the major problems on Lake Temagami only $1.7 \%$ replied: "Cutting in the Shoreline Reserve". Logging in general, presumably referring to clear-cutting operations, was ranked a major problem by $4.4 \%$. The greatest proportion of people $(80.8 \%)$ ranked pollution, garbage collection and fear of over-development as the major problem.

By official terminology the whole of the Temagami area, including the Shoreline Reserve, is under Multiple Use Management. It can only be hoped that objective assessment of the problems involved in maintaining an aesthetic shoreline will continue to allow optimization of the total potential of Lake Temagami. Such a development would be truly in the interest of all the people of Ontario.

\footnotetext{
Acknowledgment

I wish to thank those foresters of the Ontario Department of Lands and Forsters. particularly T. W. Dohly, D. E. Honeyborne and W. L. Sleeman who contributed advice and suggestions. In so doing they played a major part in the success of this experiment.
} 